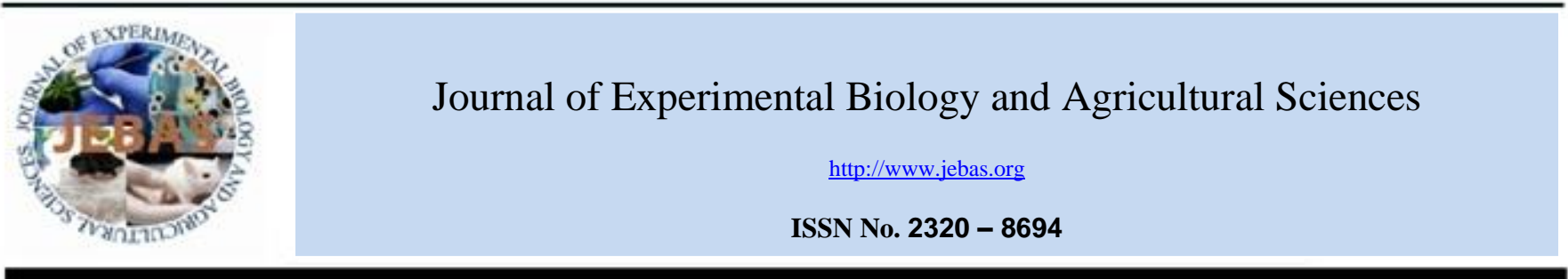

\title{
INFLUENCE OF ELEPHANT DUNG ON FECUNDITY AND GROWTH RATE OF EARTHWORM Eudrilus eugeniae
}

\section{Deepthi MP, Jijo George, P Kathireswari*}

PG \& Research Department of Zoology, Kongunadu Arts and Science College, Coimbatore, Tamil Nadu-641029, India

Received - October 04, 2019; Revision - November 15, 2019; Accepted - November 29, 2019

Available Online - December 25, 2019

DOI: http://dx.doi.org/10.18006/2019.7(6).587.692

\section{KEYWORDS \\ Cocoon \\ Earthworm \\ Fecundity \\ Seminal vesicle \\ Sperm count}

\begin{abstract}
The growth and reproduction of vermicomposting earthworm Eudrilus eugeniae is influenced by the Physico chemical parameters of organic bed materials. The present study compares the fecundity and growth rate of earthworm E. eugeniae in relation with different vermibed materials viz, elephant dung and cow dung. Hence the reproductive indices including cocoon production, fecundity, and sperm counting was recorded. For in vitro analysis of earthworm reproductive parameters viz, sperm counting, and weight of the seminal vesicle, the clitellated adult earthworms were randomly selected from the three vermireactors ( $100 \%$ elephant dung, $100 \%$ cow dung, and $50 \%$ elephant dung $+50 \%$ cow dung) after $45^{\text {th }}$ day. The results of study revealed that the earthworm reared in $50 \%$ elephant dung and $50 \%$ cow dung showed maximum reproductive potential and growth rate.
\end{abstract}

* Corresponding author

E-mail: kathireswari@gmail.com (P Kathireswari)

Peer review under responsibility of Journal of Experimental Biology and Agricultural Sciences.

Production and Hosting by Horizon Publisher India [HPI] (http://www.horizonpublisherindia.in/).

All rights reserved.
All the articles published by Journal of Experimental Biology and Agricultural Sciences are licensed under a Creative Commons Attribution-NonCommercial 4.0 International License Based on a work at www.jebas.org.

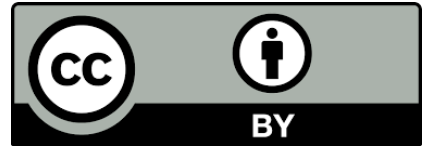




\section{Introduction}

Vermicomposting is an eco-biotechnological process in which bio oxidation and stabilization of organic waste material is made by joint action of earthworms and microorganisms (Suthar, 2007). The biotic and abiotic factors such as temperature, moisture, $\mathrm{P}^{\mathrm{H}}$, particle size and palatability of vermibed substrates can influence the composting potential of earthworms (Suthar, 2007). The vermistabilization of organic waste materials requires a detailed understanding of the biology of all potentially useful species in vermicomposting technology. It has been investigated in terms of their growth and reproduction parameters.

Based on the feeding habit, the earthworms are categorised in to three major ecological group viz., epigeics, endogeics and anecics ( $\mathrm{Du}, 2018)$. In the present study E. eugeniae has been selected as the experimental organism and it comes under the epigeic groups and it feeds on decaying organic matter such as leaf litters/ microflora, animal dung materials, kitchen waste etc., (Rombke et al., 2005), these organic wastes undergoes decomposition in the earthworm gut by the combined action of mucus and gut microbiota (Du, 2018). Eathworms are known as the cross fertilization hermaphrodites by simultaneous reciprocal insemination, transferring, and receiving sperm. In E. eugeniae the reproductive organ such as testes and ovaries are accompanied by a series of other organs. The female component contains ovaries, ovisacs, oviducts, female pores and spermathecae and the male components includes the testes and male funnels, seminal vesicles, different ducts, and male pore surrounded by atrial glands and at sexual maturity some of the external reproductive organs, such as clitellum, tubercula pubertatis and sexual papillae will develop (Cosin et al., 2011). The life cycle of E. eugeniae was found to be 60 days, a maturation time of 45 days and it have relatively high cocoon production rate (17 days) with a mean number of 2.7 hatching per cocoon and the body mass attained by this species were observed up to $2100 \mathrm{mg}$ (Viljoen \& Reinecke, 1988), hence $E$. eugeniae was widely used in the large scale vermicompsting practices. The life cycle parameters of earthworms are directly related to their basic five needs viz., living environment, temperature, moisture, population density, and quality of substrate materials (Suthar, 2007). Thus the selection of substrate material possesses a prominent role in vermicomposting process (Nurga \& Berhe, 2018).

The present study conducted to test the diet related changes in the growth and reproduction of earthworm E. eugeniae by using elephant dung with the traditional vermicomposting methods in different composition. The set up were maintained up to 45 days, then the growth and reproductive parameters were observed and analysed.

\section{Materials and Methods}

\subsection{Samples}

The elephant dung and cow dung were collected from the Perur temple and Perur cattle farm respectively. Then the fresh dung materials were subjected to precomposting up to 15 days, for reducing the toxic effects of compounds such as ammonia, salts and other harmful materials in vermibed (Garg et al., 2006).

\subsection{Source and exposure of earthworms to different experimental beddings}

The adult earthworms (E. eugeniae) were purchased from Kanuvai organic farm, Coimbatore, Tamil Nadu and were acclimatized under laboratory condition prior to experimentation. After precomposting, the bedding materials were subjected for experimental designs contains $100 \%$ ED (elephant dung), 50\% $\mathrm{ED}+50 \% \mathrm{CD}$ (50\% elephant dung and 50\% cow dung), and $100 \% \mathrm{CD}$ (100\% cow dung) in triplicates, total of 9 set up with $100 \% \mathrm{CD}$ as control. The composites $(2 \mathrm{~kg})$ were filled in the clay pot and maintained the moisture between $70-80 \%$ by adequate replenishment of water and introduced with 10 clitellated earthworms E. eugeniae, the experimental set up was maintained up to 45 days. For observing the net weight gain of the earthworm, the ten juveniles taken from each treatment and weighed the initial weight and inoculated in a separate experimental bedding containing $1 \mathrm{~kg}$ of precomposted vermibed material in triplicates.

\subsection{Cocoon hatching experiment}

The cocoon hatching experiment of E. eugeninae was performed as reported by (Suthar \& Ram, 2008). Ten cocoons from each experimental bed was randomly selected and placed in a petry dish containing $200 \mathrm{~g}$ parental bedding materials in triplicates, the petry plates were observed regularly for cocoon hatching and the newly emerged juveniles were transferred to separate container with same parental bedding materials until five days. The total number of juveniles hatched in each treatment was recorded. The hatching success was calculated in percentage by counting the total number of hatched cocoons in each experimental set up and used the following formula

Hatching success $=\frac{\text { Total number of hatched cocoons } \times 100}{\text { Total number of inoculated cocoons }}$

\subsection{Sperm count}

Sperm count and combined mass of seminal vesicles and testes were determined according to the method described by Cikutovic et al., 1993. The adult earthworms were randomly removed from 
the vermibed after $45^{\text {th }}$ day of experimentation. Then the worms with identical weight were subjected for dissection and the seminal vesicles and testes were dissected out and were weighed after removing the excess fluid by using filter paper and then placed in to $20 \mathrm{ml}$ glass vials containing $2 \mathrm{ml}$ of sperm counting fluid (5g sodium carbonate: $1 \mathrm{ml}$ neutral formalin: $100 \mathrm{ml}$ distilled water). Then the sperms were allowed to release inside the fluid by gently teasing the organ seminal vesicle and it was filled with $8 \mathrm{ml}$ of sperm counting fluid, then the entire volume was filtered through a funnel lined with double gauze $(375 \mu \mathrm{m})$ in to fresh $20 \mathrm{ml}$ vials. Finally the sperm count was done by using improved Neubauer Haemocytometer chamber. The number of spermatozoa per organ of each worm was noted by dividing the number of sperm estimated in $10 \mathrm{ml}$ of solution to the respective organs.

\subsection{Statistical Analysis}

Statistical analysis was done with the help of SPSS version 20 software. The data were analysed using one way ANOVA. The values with $\mathrm{p}<0.05$ were considered as statistically significant. Correlation between the weight of the seminal vesicle and sperm count was calculated.

\section{Results and Discussions}

\subsection{Sperm count and seminal vesicle weight}

Results obtained for reproduction parameters viz., sperm count and weight of seminal vesicle in earthworm of E. eugeniae over the experimental period have been presented in figure 1. The significant variations were observed in the total mass of seminal vesicles in the order of ED+CD $(0.262 \pm$ $0.00)>\mathrm{ED}(0.257 \pm 0.01)>\mathrm{CD}(0.222 \pm 0.02)$ (figure $1)$ and it was statistically significant $(\mathrm{F}=3.701$, $\mathrm{p}<0.05)$. This indicated that the culture media influence the total tissue mass and water content of these reproductive organs. The mean sperm count observed during the experimentation showed statistically significant in different experimental bedding materials. The maximum increase in sperm count was observed in 50\% ED+ 50\% CD (1.903x $\left.10^{8} \pm 0.111 \times 10^{8}\right)$ followed by $100 \% \operatorname{ED}\left(1.647 \times 10^{8}\right.$ $\left.\pm 0.036 \times 10^{8}\right)$ and $100 \% \mathrm{CD}\left(1.200 \times 10^{8} \pm 0.020 \times\right.$ $10^{8}$ ). The sperm count and weight of the seminal

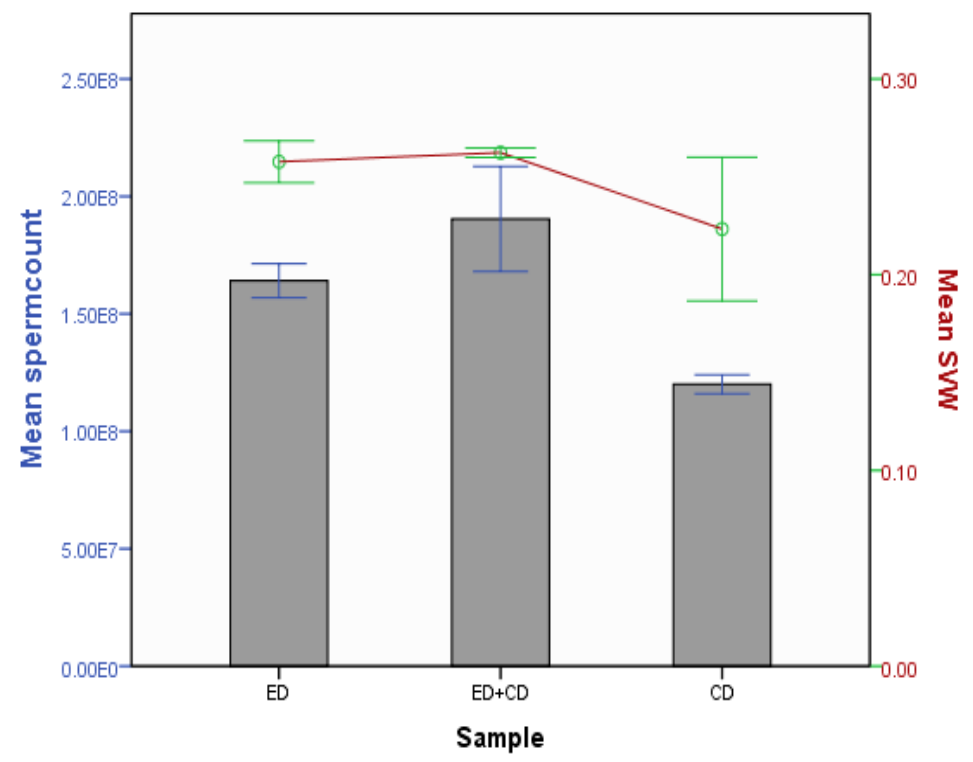

Error Bars: +/- 2 SE

Error Bars: + - 2 SE

Figure 1 Mean $( \pm S E)$ value of the sperm count and weight of the seminal vesicle $(S V W)$ of earthworm, E. eugeniae after $45^{\text {th }}$ day of exposure in vermireactors with $100 \%$ elephant dung $(E D), 50 \%$ elephant dung $+50 \%$ cow dung $(E D+C D)$, and $100 \%$ cow dung $(C D)$.

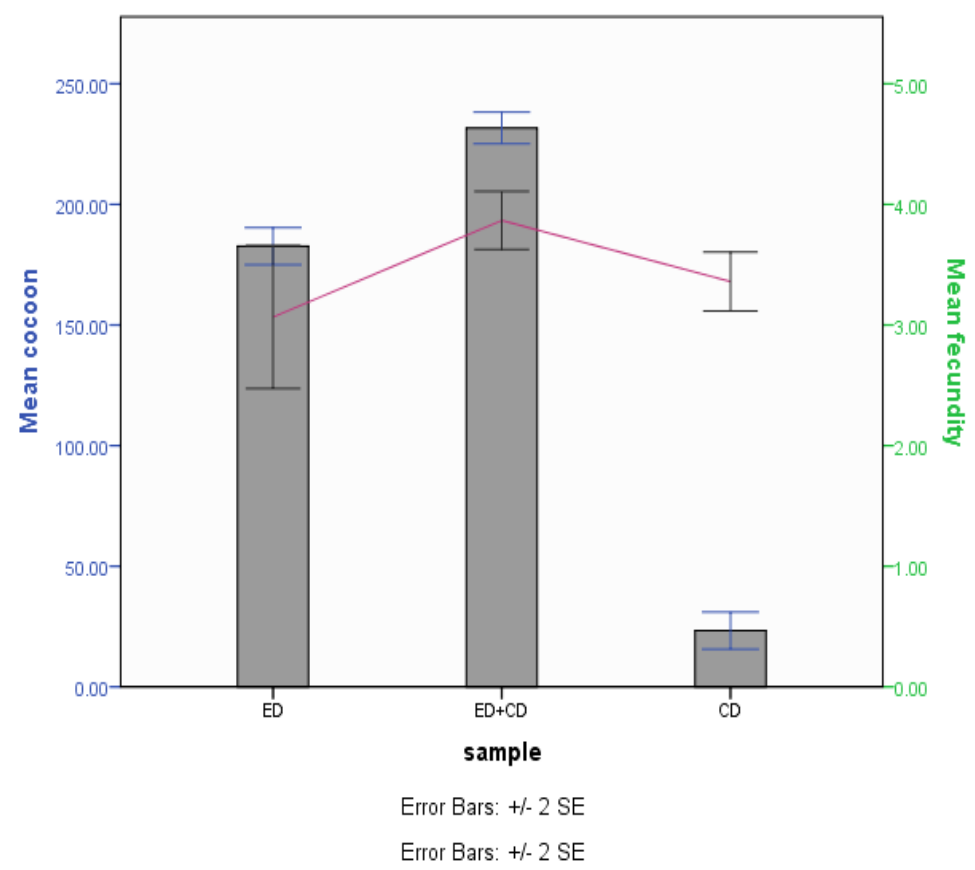

Figure 2 Mean $( \pm \mathrm{SE})$ value of cocoon production and fecundity of earthworm $E$ eugeniae after $45^{\text {th }}$ day of exposure in vermireactors with $100 \%$ elephant dung (ED), $50 \%$ elephant dung $+50 \%$ cow dung $(\mathrm{ED}+\mathrm{CD})$, and $100 \%$ cow dung $(\mathrm{CD})$ 
vesicle are positively correlated $(\mathrm{r}=0.695)$. The bedding materials viz., $100 \% \mathrm{CD}$ and $100 \% \mathrm{ED}$ is influencing the reproduction of earthworms, but combination of $50 \% \mathrm{ED}+50 \% \mathrm{CD}$ highly enhancing the sperm count and weight of seminal vesicle in earthworm E. eugeniae. The present results were correlated with the report of Garg et al., 2006 and he concluded that the earthworm growth and reproduction is directly related to the chemical nature of organic waste materials. According to Stanbrook, 2018, the elephant dung contains woody material and it will take longer time to complete the composting process; which leads to enhance the fungal activity and the final product will be an excellent soil conditioner. The report of Bonkowskie et al., 2000, clearly describes the food preference of earthworm for the soil fungi and postulated that the food source of both fungus and earthworms are decaying organic material, hence the presence of fungi in the food material indicates the quality of food for the earthworm. Similarly, the fungal cell walls composed of chitin that contains high natural proteins, amino polysaccharides, so the occurrence of fungi during vermicomposting process became additional supplement to the earthworms which amplified number and weight of the earthworms.

\subsection{Rate of Cocoon production and Fecundity}

The rate of cocoon production reflects the earthworm reproductive efficiency in the particular vermibed material (Banu et al., 2005). The cocoon production and fecundity of earthworm E. eugeniae after $45^{\text {th }}$ day were presented in figure 2 . The significant differences were observed in both cocoon production $(\mathrm{F}=882.532$, $\mathrm{p}<0.5)$ and fecundity $(\mathrm{F}=4.301, \mathrm{P}<0.05)$ of earthworms. The $50 \% \mathrm{ED}+50 \%$
CD showed maximum number of cocoons $(231.66 \pm 3.28)$ and fecundity (3.866 \pm 0.12 ) when compared to $100 \% \mathrm{ED}$ and $100 \%$ $\mathrm{CD}$ alone. The minimum number of cocoons was observed in $100 \%$ CD (23.33 \pm 3.84$)$, whereas fecundity was found to be minimum in $100 \% \mathrm{ED}(3.08 \pm 0.21)$. The total hatching and hatching percentage was higher in $50 \% \mathrm{ED}+50 \% \mathrm{CD}$ (table 1) vermibed materials and thus significant difference was arrived $(\mathrm{P}$ $<0.05)$. The hatching percentage 83.3 in the current study were higher than the reports of Suthar, 2007 and Ali \& Kashem, 2018 with $73.19 \%$ and $75.3 \%$ respectively . supportively the report of Kabi et al. (2018), the cocoon production, cocoon weight, and hatching success of earthworm will vary according to different media used in vermicomposting. The differences in the cocoon production in various substrate materials might be due the interaction of earthworms to the physicochemical properties of the food materials. Thus the quality of food material is one of the main determinant and important factors to express the reproduction and growth rate in earthworm (Sharma \& Garg, 2018 ).

\subsection{Biomass}

The initial biomass of the juveniles was ranged between $0.010 \mathrm{~g}$ $0.012 \mathrm{~g} /$ individual and the weight gain of an individual on $45^{\text {th }}$ day was calculated in different vermibed materials. The worms cultured in 50\% ED $+50 \% \mathrm{CD}$ vermibed material reached maximum about $2.80 \pm 0.08 \mathrm{~g} /$ individual on $45^{\text {th }}$ day followed by $100 \% \mathrm{ED}$ and $100 \% \mathrm{CD}$ (table 2). The treatment with $100 \% \mathrm{ED}$ and $100 \% \mathrm{CD}$ alone showed comparatively lower growth rate and significant differences were noticed. During experimentation the net

Table 1 Hatching success of Eudrilus eugeniae in different vermibed materials

\begin{tabular}{|c|c|c|c|}
\hline Vermibed material & Total hatchlings & Hatchling percentage & $\begin{array}{l}\text { Hatching /cocoon } \\
\text { (Fecundity) }\end{array}$ \\
\hline $100 \% \mathrm{ED}$ & $26.33 \pm 0.88$ & $76.66 \pm 3.32$ & $3.06 \pm 0.29$ \\
\hline $50 \% \mathrm{ED}+50 \% \mathrm{CD}$ & $31.33 \pm 1.4$ & $83.3 \pm 3.33$ & $3.86 \pm 0.12$ \\
\hline $100 \% \mathrm{CD}$ & $19.66 \pm 2.02$ & $66.66 \pm 3.33$ & $3.36 \pm 0.12$ \\
\hline $\mathrm{F}$ & 14.683 & 9.333 & 4.301 \\
\hline Sig. & 0.005 & 0.014 & 0.069 \\
\hline
\end{tabular}

$\mathrm{P}<0.05$ is significant, ED- elephant dung, $\mathrm{CD}$ - cow dung

Table 2 Growth differences of Eudrilus eugeniae in different vermibed materials

\begin{tabular}{|c|c|c|c|}
\hline Vermibed material & Initial weight (g) & Weight after $45^{\text {th }}$ day & Net weight gain \\
\hline $100 \% \mathrm{ED}$ & $0.012 \pm 0.0011$ & $1.83 \pm 0.05$ & $1.82 \pm 0.05$ \\
\hline $50 \% \mathrm{ED}+50 \% \mathrm{CD}$ & $0.010 \pm 0.0012$ & $2.80 \pm 0.08$ & $2.67 \pm 0.16$ \\
\hline $100 \% \mathrm{CD}$ & $0.012 \pm 0.0013$ & $1.97 \pm 0.09$ & $1.95 \pm 0.09$ \\
\hline $\mathrm{F}$ & 0.893 & 6.607 & 6.648 \\
\hline Sig. & 0.458 & 0.030 & 0.030 \\
\hline
\end{tabular}

Journal of Experimental Biology and Agricultural Sciences

http://www.jebas.org 
weight gained by the earthworm $E$. eugeniae expressed in the following order $50 \% \mathrm{ED}+50 \% \mathrm{CD}(2.67 \pm 0.16))>100 \% \mathrm{CD}$ $(1.95 \pm 0.09)>100 \% \mathrm{ED}(1.82 \pm 0.05)$. In the present study the weight gained by the earthworm E. eugeniae was very higher than the report of Coulibaly \& Bi (2010), those who reported that the peak weight achieved in the $12^{\text {th }}$ week by E. eugeniae in the animal waste of cow, sheep, pig, and chicken were about $1.01 \pm 0.52$ g/individual, $1.318 \pm 0.07 \mathrm{~g} /$ individual, $0.87 \pm 0.11 \mathrm{~g} /$ individual, and $1.69 \pm 0.15 \mathrm{~g} /$ individual respectively. Suthar, 2007 reported differences in biomass of composting earthworm in different organic substrates and obtained in the range about $1522.9 \pm 1.10$ $\mathrm{mg}$ in E. eugeniae after $17^{\text {th }}$ week. In the present study elephant dung highly influence the growth and reproduction of earthworm E. eugeniae.

Evidently report of Suthar 2007 on the growth parameters of earthworm depends upon the chemical nature of organic waste that is favoured by the supplementation of easily metabolizable organic matter, non-assimilated carbohydrates and low concentration of growth retarding substances. Vodounnou et al., 2016 studied the effect of animal waste and vegetable compost on production and growth of Eisenia fetida during vermiculture and proved that the growth and reproduction of earthworm is influenced by the biochemical quality of the substrate materials. Current results relate this hypothesis, since the biomasses of earthworm were varied in each experimental bed materials and it was statistically significant.

\section{Conclusion}

The present study concluded that the supplementation of elephan dung along with the conventional vermibed materials (cow dung) have positive impact on earthworm growth and fecundity. While adding the elephant dung in the vermireactor it will enhance the texture and moisture retention capabilities thus, it aerates the whole unit and make it easier for the worms to consume and for getting required supplements. Elephants are herbivores and their dung contains undigested plant fibres, because the digestibility of both wild and captive elephant was estimated about 30-45\% and 35- 39 $\%$ respectively. So an elephant can produce $110 \mathrm{~kg}$ of dung per day. The open dumping of such a huge quantity of dung materials will create environmental pollution. So it can be used for vermiculture as feed materials as well as recommended to use for large scale production based on the availability of waste materials.

\section{Acknowledgement}

The authors wish to thank the management of Kongunadu Arts and Science College, Coimbatore, Tamil Nadu, India.

\section{Conflict of Interest}

The authors declare that they have no conflict of interest.
References

Ali S, Kashem MA (2018) Life cycle of vermicomposting earthworms Eisenia fetida and Eudrilus eugeniae under laboratory conditions. Biomedical Journal of Scientific and Technical Research 10: 1-4.

Banu JR, Esakkiraj S, Nagendran R, Logakanthi S (2005) Biomanagement of petrochemical sludge using an exotic earthworm Eudrilus eugineae. Journal of Environmental Biology 26:43-47.

Cikutovic MA, Fitzpatrick LC, Venables BJ, Goven AJ (1993) Sperm count in earthworms (Lumbricus terrestris) as a biomarker for environmental toxicology: Effects of cadmium and chlordane. Environmental Pollution 81:123-125.

Cosín DJD, Novo M, Fernández R (2011) Reproduction of earthworms: Sexual selection and parthenogenesis. In Biology of Earthworms. Springer Nature publication Pp. 69-86.

Coulibaly SS, Bi IAZ (2010) Influence of animal wastes on growth and reproduction of the African earthworm species Eudrilus eugeniae (Oligochaeta). European Journal of Soil Biology 46: $225-229$.

Bonkowski M, Griffiths BS, Karl Ritz (2000) Food preferences of earthworms for soil fungi. Pedobiologia 44: 666-676.

Du JH (2018) The earthworm gastrointestinal effect on the release of organic bound residues in soils. Earth and Environmental Science 128: 1-5.

Garg VK, Kaushik P, Dilbaghi N (2006) Vermiconversion of wastewater sludge from textile mill mixed with anaerobically digested biogas plant slurry employing Eisenia foetida. Ecotoxicology and Environmental Safety 65: 412-419.

Kabi F, Kayima D, Kigozi A, Mpingirika EZ, Kayiwa, Okello D (2018)Effect of different oragnic substarte on reproductive biology growth and offtake of the african night crawler earthworm (Eudrilus eugeniae). Proceedings of 4th African Organic Conference.

Nurga Y, Berhe H (2018) Evaluation of different earthworm species and food sources for their vermiculture and vermicompost outputs in Raya Azebo District, South Tigray. In: Agegnehu G, Gurmu G, Abera T, Muleta D (Eds.) Soil Fertility and Plant Nutrient Management Published by Ethiopian Institute of Agricultural Research Pp. 171-176.

Rombke J, Jansch, Didden W (2005) The use of earthworms in ecological soil classification and assessment concepts. Ecotoxicology and Environmental Saftety 62: 249-265. 
Sharma K, Garg VK (2018). Comparative analysis of vermicompost quality produced from rice straw and paper waste employing earthworm Eisenia fetida. Bioresource Technology 250: 708-715.

Stanbrook RA (2018) Assessing the nutrient status of elephant dung in the Aberdare National Park, Kenya. Pachyderm 59: 86-90.

Suthar S (2007) Influence of different food sources on growth and reproduction performance of composting epigeics: Eudrilus eugeniae, Perionyx excavatus and Perionyx sansibaricus. Applied Ecology and Environmental Research 5: 79-92.

Suthar S, Ram S (2008) Does substrate quality affect earthworm growth and reproduction patterns in vermicomposting systems? A study using three popular composting earthworms. International Journal of Environment and Waste Managment 2: 584-600.

Viljoen SA, Reinecke AJ (1988) The number, size and growth of hatchlings of the African nightcrawler, Eudrilus eugeniae (Oligochaeta). Revue d'Ecologie et de Biologie Du Sol (France).

Vodounnou D, Kpogue DNS, Tossavi CE, Mennsah GA, Fiogbe ED (2016) Effect of animal waste and vegetable compost on production and growth of earthworm (Eisenia fetida) during vermiculture. International Journal of Recycling of Organic Waste in Agriculture 5: 87-92.

Journal of Experimental Biology and Agricultural Sciences http://www.jebas.org 